Author: C-J Pretorius

THIRD PARTY FRAUD INDUCING MATERIAL MISTAKE

SLIP KNOT INVESTMENTS 777 (PTY) LTD V DU TOIT 20114 SA 72 (SCA)

ISSN 1727-3781

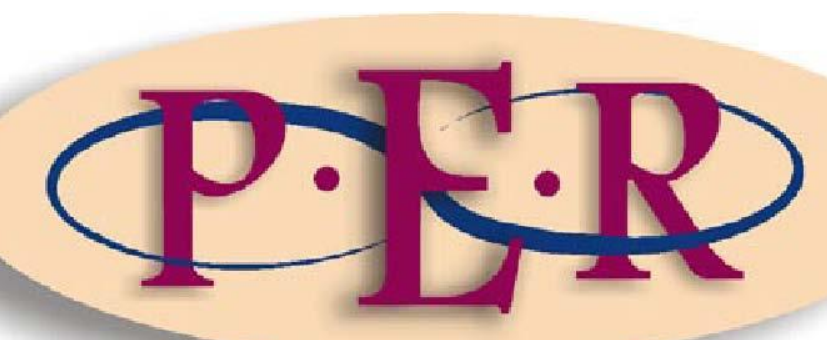

2011 VOLUME 14 No 7

http://dx.doi.org/10.4314/pelj.v14i7.8 


\section{THIRD PARTY FRAUD INDUCING MATERIAL MISTAKE \\ SLIP KNOT INVESTMENTS 777 (PTY) LTD V DU TOIT 20114 SA 72}

(SCA)

\section{C-J Pretorius ${ }^{*}$}

\section{$1 \quad$ Introduction}

A problem that has perplexed the courts for some time, and to which there has been no clear answer, is whether the material mistake of a contractant induced solely by the deliberate interventions of an independent third party is sufficient to sustain a plea of iustus error (on the part of the contract denier) or, conversely, a lack of reasonable reliance (on the part of the contract assertor) raised by the mistaken party. A third party may be regarded as someone who does not act in collusion with, or as the agent of, either of the contractual parties. Consequently, the conduct of the third party cannot be attributed directly to either party. ${ }^{1}$ Deliberate third-party conduct generally tends to be problematic as regards the law of obligations. ${ }^{2}$ Within the realm of contract it manifests as fraudulent misrepresentation by the third party causing a mistake (either material or non-material) on the part of a contractant. The position in regard to non-material mistake has been settled for some time, but cases dealing with material mistake caused in this manner tend to reflect inconsistency and contradiction. On the whole the Supreme Court of Appeal has been silent on the matter, ${ }^{3}$ but recently in Slip Knot Investments $v$ Du Toit this court was not prepared to uphold a plea of iustus error where the mistake in question was caused by third parties and not the contract assertor. Although the court's decision provides some much needed direction, it is suggested that there may well be exceptional situations

\footnotetext{
* Chris-James Pretorius. BLC LLB LLD. Professor in Private Law, Unisa. E-Mail: pretocj1@unisa.ac.za.

1 See Van der Merwe et al Contract: General Principles 108.

2 See more comprehensively Pretorius 2011a THRHR 65 and further, Pretorius 2011b THRHR 182 and further.

3 Although in Saambou-Nasionale Bouvereniging v Friedman 19793 SA 978 (A) 1000B Jansen JA appears to have at least entertained the notion that the fraudulent misrepresentation of a third party causing dissensus could influence the existence of a contract.

$4 \quad$ Slip Knot Investments v Du Toit 20114 SA 72 (SCA).
}

$187 / 261$ 
where contractual liability should not lie. This note examines third-party fraud within the context of the law of mistake in the light of the approach adopted by the court.

\section{Facts}

The respondent was a sixty-year old farmer and a trustee of a trust along with his brother and the latter's son. The trust was created by the respondent's brother, who was a beneficiary of the income of the trust and administered the trust solely in his own interests and those of his heirs. The respondent had no interest in the trust assets or its income. The trustees, including the respondent, signed a deed of suretyship in favour of the appellant as security for advancing a sum of R6 million to the trust. Judgment was obtained against the trust and sureties after the trust failed to adhere to the terms of a settlement agreement. The sequestration of the trust and the estate of the respondent's brother ensued. The respondent admitted signing the deed of suretyship, but denied that he was liable as surety, alleging that he had signed by mistake and without the intention to incur contractual liability. He brought an application for rescission of the judgment against him as surety, which was granted. The main application subsequently came before Kruger $\mathrm{J}$ in the Free State High Court who dismissed the appellant's application for judgment against the respondent but gave leave to appeal to the Supreme Court of Appeal. ${ }^{5}$

The facts material to the signing of the suretyship by the respondent are as follows: on the particular day the respondent's nephew telephoned the respondent's friend, one Potgieter, and told her that he had certain documents that required the respondent's signature. They concerned business transactions of his father in Africa and had to be signed urgently and returned by telefacsimile the same day. The respondent knew of his brother's dealings in Africa and regarded them as risky. At the relevant time the respondent was on his farm. Potgieter relayed the conversation and informed him that the documents had to be signed before a commissioner of oaths. He was, however, busy and requested her to wait. After two further calls to her from his nephew, Potgieter again spoke to the respondent and emphasised the urgency of the matter. She gave him a bundle of documents comprising some 75

5 Slip Knot Investments v Du Toit 20114 SA 72 (SCA) para 3.

$188 / 261$ 
pages pertaining to the R6 million loan to the trust, which had already been signed by his brother and nephew. Amongst these documents was the suretyship. The respondent was prepared to sign the documents without reading them because he thought that he was not personally affected and the two other trustees had already signed. In consequence, he assumed that his brother and nephew had agreed to the terms on which the appellant would advance monies to the trust and that his signature was required as a mere formality. The respondent and his son went to the manager of the First National Bank in Luckhoff, a commissioner of oaths, to sign the documents. The manager happened to know of the transaction which somehow reassured the respondent that the documents related to his brother's trust only. Thereafter the documents were duly signed and sent by telefacsimile to the respondent's brother. Although he did not read the documents the respondent stated that he never expected a suretyship to be amongst them and no one drew his attention to the suretyship. ${ }^{6}$

\section{Decision}

The decisions of the court a quo and Supreme Court of Appeal differ markedly on the question of whether or not the respondent's plea of iustus error was sustainable, which is a reflection of the difficulty that the courts generally have experienced in adjudicating similar cases.

\subsection{Court a quo}

In the court a quo Kruger $\mathrm{J}$ found that the respondent's mistake was reasonable. In reaching this conclusion he emphasised the following: the respondent was a farmer who had nothing to do with the business of the trust and the loan to it by the appellant. He was further not a businessman and knew that the documents related to his brother's risky venture in Africa, which did not concern him. It was also because he was put under considerable pressure to sign them forthwith that the respondent believed that the documents did not affect him. Furthermore, there were no negotiations between the appellant and respondent. The bank manager, in addition,

6 Slip Knot Investments v Du Toit 20114 SA 72 (SCA) paras 4-7. 
informed the respondent that he was aware of the transaction and that had set the respondent's mind at rest. The suretyship was further not prominent amongst the documents presented to the respondent for signing. Kruger $\mathrm{J}$ found that in a sense the respondent's brother and nephew had acted as the appellant's agents and should have warned him of the suretyship, and that the respondent had no reason to expect a personal suretyship to be among the documents he signed. ${ }^{7}$

\subsection{Supreme Court of Appeal}

The crisp question on appeal was whether the respondent could be absolved from liability under the suretyship where his (material) mistake was not induced by the other contractant (the appellant), ${ }^{8}$ but rather the apparently fraudulent omission of third parties (his nephew and primarily his brother) to inform him of the nature of the document (suretyship) that he had been called upon to sign. ${ }^{9}$ In delivering the judgement of the Supreme Court of Appeal, Malan JA affirmed that generally a contractual party is not obliged to inform the other party of the terms of the proposed agreement, ${ }^{10}$ unless there are provisions that could not reasonably have been expected to be part of the contract. ${ }^{11}$ While the court a quo concluded that the suretyship was "hidden" in the bundle of documents, Malan JA found nothing objectionable in the documents and that even a cursory glance at them would have alerted the respondent to the deed of suretyship. There was further nothing misleading in the bundle and the inclusion of a suretyship among the documents was not unexpected. The learned judge was critical of the emphasis placed in the court $a$ quo on the fact that the respondent was a farmer and not a businessman, and that he had nothing to do with the trust and loan advanced to it. The respondent was a trustee of the trust; he must have known what a trust was and what the duties and responsibilities of a trustee were. Malan JA applied the reliance theory to the facts

7 Slip Knot Investments v Du Toit 20114 SA 72 (SCA) para 10.

8 It was clear that the fraud or misrepresentation of the respondent's relatives could not be attributed to the appellant (para 11).

9 Slip Knot Investments $v$ Du Toit 20114 SA 72 (SCA) paras 1-2.

10 With reference to Constantia Insurance Co Ltd v Compusource (Pty) Ltd 20054 SA 345 (SCA) para 19.

11 With reference to Afrox Healthcare Bpk $v$ Strydom 20026 SA 21 (SCA) para 36; see also Fourie $v$ Hansen 20011 All SA 510 (W) 516. See also Potgieter v British Airways plc 20053 SA 133 (C) 140. 
and concluded that the appellant was entitled to rely on the respondent's signature as a surety in the same manner as it was entitled to rely on his signature as a trustee. The respondent further acted entirely on what was conveyed to him by his nephew through Potgieter. The appellant made no misrepresentation to him and there was no suggestion that the appellant knew or ought, as a reasonable person, to have known of the respondent's mistake. In consequence, the appeal was upheld and the respondent was held liable under the suretyship. ${ }^{12}$

\section{$4 \quad$ Commentary}

There is authority for both the decision in the court a quo and the Supreme Court of Appeal. It is, however, suggested that the approach of the Supreme Court of Appeal is preferable, but the question that begs is if in all instances where the material mistake of a contractant has been caused by the fraud of a third party contractual liability nevertheless should lie as a matter of strict principle. After all, one is potentially dealing with two innocent parties: ${ }^{13}$ the contract denier's mistake has been induced by the fraudulent conduct of a third party, while the reliance of the contract assertor has been caused by the contract denier. Why should the contract assertor necessarily be in a preferential position to the contract denier? As will be suggested, much depends on which approach to material mistake weighs heavier as a matter of legal policy, ${ }^{14}$ but that in itself should not preclude exceptions to the general rule in appropriate circumstances.

\subsection{Contradiction in case law}

The Supreme Court of Appeal seemed to accept that the third parties who induced the respondent's mistake acted fraudulently, and it is highly probable that they did. ${ }^{15}$ Decisions on third-party fraud inducing material mistake reflect a fair measure of

12 Slip Knot Investments v Du Toit 20114 SA 72 (SCA) para 12.

13 See Christie and Bradfield Christie's The Law of Contract 184; Floyd and Pretorius 1992 THRHR 673.

14 Christie and Bradfield Christie's The Law of Contract 184 emphasise "the value, especially in commercial matters, of being able to assume that the signatory is bound by his signature".

15 Compare paras 8 and 11 of Slip Knot Investments $v$ Du Toit 20114 SA 72 (SCA). 
inconsistency, especially where the iustus error doctrine is involved. In some cases the courts have been very tentative about this issue ${ }^{16}$ and in others they have avoided addressing it if at all possible. ${ }^{17}$ The case law has been analysed in detail elsewhere and does not bear repeating in any detail. ${ }^{18}$ For present purposes it is sufficient to state that in some instances the courts have been prepared to absolve a party from contractual liability where his or her mistake has been caused by the fraudulent interventions of a third party, ${ }^{19}$ while on other occasions they have not. ${ }^{20}$ The rationales for these decisions, however, have not always been convincing. Academic opinion tends to be against recognising that the fraud of the third party necessarily releases the mistaken party from liability. ${ }^{21}$

Two factors in particular appear to have influenced the courts in this regard: firstly, the law relating to actionable misrepresentation, ${ }^{22}$ where the position is that unless the fraud emanates from one of the contracting parties it has no effect on the contract:;3 and secondly, the question of negligence on the part of the contract denier either to justify liability where present ${ }^{24}$ or to absolve the mistaken party where

16 See Saambou-Nasionale Bouvereniging v Friedman 19793 SA 978 (A) 1000B.

17 See e.g. Siffman v Kriel 1909 TS 538 546; Khan v Naidoo 19893 SA 724 (N) 727.

18 See Pretorius 2011b THRHR 186-190; and further Christie and Bradfield Christie's The Law of Contract 183-184, 282, 331-332; Lewis 1987 SALJ 371 and further; Hutchison and Van Heerden 1987 SALJ 529-530.

19 See e.g. Musgrove and Watson (Rhod) (Pvt) Ltd v Rotta 19782 SA 918 (R); Kok v Osborne 19934 SA 788 (SE); Musgrove and Watson (Rhodesia) Ltd $v$ Rotta 19784 SA 656 (RA) 658A-B; Western Province Wine Depot Ltd v Bellingham 19661 SA 349 (T) 353.

20 See e.g. Standard Bank v Du Plooy; Standard Bank v Coetzee 189916 SC 161; Standard Credit Corporation Ltd v Naicker 19872 SA 49 (N); Trans-Drakensberg Bank Ltd v Guy 19641 SA 790 (D) 797C-D; Khan v Naidoo 19893 SA 724 (N) 727.

21 Compare e.g. Wessels Wessels' Law of Contract para 1122; Forsyth and Pretorius Caney's The Law of Suretyship 67; Van der Merwe et al Contract: General Principles 47; Lewis 1987 SALJ 374 and further; Christie and Bradfield Christie's The Law of Contract 331.

22 That is culpable misrepresentation inducing non-material mistake.

23 Karabus Motors (1959) Ltd $v$ Van Eck 19621 SA 451 (C) 453D; Fedbond Nominees (Pty) Ltd $v$ Meier 20081 SA 458 (C) 462F-H; Van der Merwe et al Contract: General Principles 108; Kerr Principles of the Law of Contract 279; Van Rensburg et al "Contract" 236; Hutchison and Pretorius Law of Contract 122. See further Saambou-Nasionale Bouvereniging v Friedman 1979 3 SA 978 (A) 999-1000; Bodemer v American Insurance Co 19612 SA 662 (A). In Standard Credit Corporation Ltd $v$ Naicker 19872 SA 49 (N) 51J-52A Milne JP referred with apparent approval to Karabus Motors (1959) Ltd v Van Eck 19621 SA 451 (C) 453D where the court formulated the rule as follows: "It is a general rule of our law that if the fraud which induces a contract does not proceed from one of the parties, but from an independent third person, it will have no effect upon the contract. The fraud must be the fraud of one of the parties or of a third party acting in collusion with, or as the agent of, one of the parties".

24 See e.g. Standard Credit Corporation Ltd v Naicker 19872 SA 49 (N) 53H-J. 
absent. ${ }^{25}$ Both factors are open to criticism. The analogy with misrepresentation is perhaps at best a useful guideline ${ }^{26}$ since the iustus error doctrine and the reliance theory do not apply in that instance, but certainly do where material mistake is in question. ${ }^{27}$ The fault principle is more problematic and its application within the realm of mistake has drawn criticism on the basis that a comparison of degrees of fault between parties is unworkable. ${ }^{28}$ At times the use of fault has also been questioned by the judiciary. ${ }^{29}$ It is suggested that although fault is not a strict requirement under the tests for reliance or iustus error it generally remains a useful tool when balancing the equities of cases of dissensus. ${ }^{30}$ Within the context of third-party fraud, however, it appears to be superfluous, because when a party has been deceived by the fraudulent conduct of another, surely his or her negligence is nullified by the intentional act of the deceiver ? $^{31}$ Moreover, virtually in all instances of material mistake induced in this manner the negligence of the contract denier has in main consisted of not reading a contractual document before signing it. ${ }^{32}$ The courts vary in their interpretation of such conduct, at times labelling it negligent, while at other times not. ${ }^{33}$ Focusing on negligence simply does not seem to take the matter any further: if the contract denier was not negligent and actually read the contractual document before signing it, then surely there would have been no mistake to speak of. Rather, the point is that the fraudster has managed to lull the mistaken party into

25 See e.g. Kok v Osborne 19934 SA 788 (SE) 800D.

26 Christie and Bradfield Christie's The Law of Contract 331 are of the opinion that "[o]n balance it seems slightly preferable that the rule stated in Karabus Motors (1959) Ltd v Van Eck 19621 SA 451 (C) 453 should prevail and the third party's fraud should have no effect on the contract." In the present matter, however, Malan JA was mindful of the fact that Karabus Motors applied to non-material errors and not the issue of mistake proper (Karabus Motors (1959) Ltd $v$ Van Eck 19621 SA 451 (C) 76A-B).

27 See Saambou-Nasionale Bouvereniging v Friedman 19793 SA 978 (A) 1000B; cf Hutchison and Van Heerden 1987 SALJ 530.

28 See Lewis 1987 SALJ 376; Hutchison and Van Heerden 1987 SALJ 528; cf Février-Breed 1996 THRHR 212 and further.

29 Compare e.g. Sonap Petroleum (SA) (Pty) Ltd v Pappadogianis 19923 SA 234 (A) 240C; Davids $\checkmark$ Absa Bank Bpk 20053 SA 361 (C) 369H.

30 See Van der Merwe et al Contract: General Principles 49; Van der Merwe and Van Huyssteen 1993 TSAR 496; Floyd 1996 THRHR 569; Pretorius 2005b THRHR 587.

31 See further in this regard Pretorius 2011b THRHR 189; Floyd and Pretorius 1992 THRHR 671672; cf Kerr Principles of the Law of Contract 278-279; Lewis 1987 SALJ 374.

32 The resulting mistake is usually one regarding the nature of the juristic act in question or rather an error in negotio (see Joubert General Principles of the Law of Contract 73, 77; Van der Merwe et al Contract: General Principles 26; Hutchison and Pretorius Law of Contract 88).

33 Contrast e.g. Standard Credit Corporation Ltd v Naicker 19872 SA 49 (N) 51 and further with Kok v Osborne 19934 SA 788 (SE) 799-800. 
not bothering to read a contractual document before signing it. Should the latter be penalised simply because the deceiver has succeeded in perpetrating the fraud? ${ }^{34}$ It is suggested that in the light of the apparent difficulties surrounding negligence within this context it seems best to leave it out of the enquiry altogether..$^{35}$

Fortunately, the decision in Slip Knot brings an element of certainty as to how such matters should be dealt with. As a general proposition the Supreme Court of Appeal considered the fraudulent conduct of a third party inducing operative mistake not to necessarily preclude contractual liability. ${ }^{36}$ The position in regard to mistake is then broadly similar to that regarding the law of misrepresentation. But what remains to be seen is if sense can be made of past judicial statements acknowledging that there may be instances when third party fraud will in fact act as a bar to contractual liability. ${ }^{37}$ It is important to note that while Malan JA did refer to some of the case law, he did not overrule any decisions or aspects thereof. ${ }^{38}$ In principle, then, it seems that exceptions to the general rule are indeed possible.

\subsection{Third party fraud and the tests for iustus error and reliance}

Even a casual glance at the classic formulations in positive law of the iustus error doctrine and the reliance theory reveals that they do not make provision for material mistake induced by third-party fraud. ${ }^{39}$ As regards iustus error, Malan JA referred to the statement of principle firstly in George $v$ Fairmead (Pty) Ltd:

Has the first party - the one who is trying to resile - been to blame in the sense that by his conduct he has led the other party, as a reasonable man, to believe that he

34 See Kerr Principles of the Law of Contract 278-279.

35 See further Pretorius 2011b THRHR 190-191; Lewis 1987 SALJ 376.

36 See especially paras 11-12 of Slip Knot Investments $v$ Du Toit 20114 SA 72 (SCA).

37 Compare e.g. Saambou-Nasionale Bouvereniging v Friedman 19793 SA 978 (A) 1000B; Musgrove and Watson (Rhodesia) Ltd v Rotta 19784 SA 656 (RA) 658B; Musgrove and Watson (Rhod) (Pvt) Ltd v Rotta 19782 SA 918 (R) 925D; Kok v Osborne 19934 SA 788 (SE) 800C-D; Standard Credit Corporation Ltd v Naicker 19872 SA 49 (N) 52B-C; Standard Bank v Du Plooy; Standard Bank v Coetzee 189916 SC 161172.

38 Slip Knot Investments $v$ Du Toit 20114 SA 72 (SCA) 76.

39 There have been further adaptations of the iustus error doctrine (e.g.Brink $v$ Humphries and Jewell (Pty) Ltd 20052 SA 412 (SCA) para 8), but they have not gained general acceptance and tend to be problematic (see further Pretorius 2009 Obiter 767-768 and the authorities cited there). 
was binding himself? ... If his mistake is due to a misrepresentation, whether innocent or fraudulent, by the other party, then, of course, it is the second party who is to blame, and the first party is not bound. ${ }^{40}$

And secondly in National and Overseas Distributors Corporation (Pty) Ltd $v$ Potato Board:

Our law allows a party to set up his own mistake in certain circumstances in order to escape liability under a contract into which he has entered. But where the other party has not made any misrepresentation and has not appreciated at the time of acceptance that his offer was being accepted under a misapprehension, the scope for a defence of unilateral mistake is very narrow, if it exists at all. At least the mistake (error) would have to be reasonable (justus) and it would have to be pleaded. ${ }^{41}$

Both statements rely heavily on a misrepresentation ${ }^{42}$ on the part of the contract assertor to render the mistake of the contract denier reasonable. Although traditionally the courts have regarded misrepresentation as the most important factor in this regard, ${ }^{43}$ there are other circumstances in which a mistake may be found to be excusable. Since the iustus error approach is regarded as an indirect manifestation of the reliance theory ${ }^{44}$ it follows that a mistake may be iustus where there is a lack of reasonable reliance on the part of the contract assertor. ${ }^{45}$ More specific to our present purposes, however, there are indications in case law that a mistake may be reasonable simply because the contract denier acted reasonable and without fault. ${ }^{46}$

40 George v Fairmead (Pty) Ltd 19582 SA 465 (A) 471A-D. Affirmed in e.g. Du Toit v Atkinson's Motors Bpk 19852 SA 893 (A) 903I-J; Spindrifter (Pty) Ltd v Lester Donovan (Pty) Ltd 19861 SA 303 (A) 315A-B; Hlobo v Multilateral Motor Vehicle Accidents Fund 20012 SA 59 (SCA) 65J$66 \mathrm{~B}$.

41 National and Overseas Distributors Corporation (Pty) Ltd v Potato Board 19582 SA 473 (A) 479G-H. Affirmed in e.g. Hlobo v Multilateral Motor Vehicle Accidents Fund 20012 SA 59 (SCA) 66G-I; Stiff v Q Data Distribution (Pty) Ltd 20032 SA 336 (SCA) 341G; Brink v Humphries and Jewell (Pty) Ltd 20052 SA 419 (SCA) 430A-C.

42 A misrepresentation can occur either by positive conduct or by omission where a duty to speak exists in the circumstances (see Van der Merwe et al Contract: General Principles 47-48; Hutchison and Pretorius Law of Contract 100-102; Pretorius 2004b THRHR 551-553).

43 See Lubbe and Murray Farlam and Hathaway - Contract 165-167; Hawthorne and Pretorius Contract Law Casebook 46-47.

44 Van Rensburg 1986 THRHR 453; Hutchison and Van Heerden 1987 SALJ 525; Pretorius 2004b THRHR 558.

45 Prins v Absa Bank Ltd 19983 SA 904 (C) 908; Van der Merwe et al Contract: General Principles 48-49; Hutchison and Van Heerden 1987 SALJ 524; Hutchison and Pretorius Law of Contract 103; Pretorius 2004 THRHR 553.

46 Compare e.g. Horty Investments (Pty) Ltd v Interior Acoustics (Pty) Ltd 19843 SA 537 (W) 539; Kok v Osborne 19934 SA 788 (SE) 800; see Prins v Absa Bank 19983 SA 904 (C) 908; 
This seems to have been the line taken by the court a quo in Slip Knot. As previously mentioned, it is this latter interpretation of iustus error that has clouded the issue of third-party fraud inducing material mistake, because it is quite plausible that a mistake may be regarded as excusable merely because it was occasioned by the fraudulent misrepresentation of a third party. ${ }^{47}$ Aside from the fact that the iustus error doctrine does not seem to produce consistent results, the problem with this reasoning is that on the same facts one could infer reasonable mistake on the part of the contract denier (for being induced by the fraud of a third party ${ }^{48}$ ) and reasonable reliance on the part of the contract assertor (for being induced by the contract denier $\left.{ }^{49}\right) .{ }^{50}$ The only way to resolve this conundrum is to acknowledge that since the iustus error approach is but an indirect expression of the reliance theory, the former should bow to the latter when the two are in a state of conflict. ${ }^{51}$ It is therefore suggested that within the context of third-party fraud the iustus error approach should simply not be applied. ${ }^{52}$

In Slip Knot Investments $v$ Du Toit ${ }^{53}$ Malan JA also referred to the authoritative formulation of the reliance theory in Sonap Petroleum (SA) (Pty) Ltd $v$ Pappadogianis, ${ }^{54}$ which he regarded as the decisive question in such cases:

Spindrifter (Pty) Ltd v Lester Donovan (Pty) Ltd 19861 SA 303 (A) 316. See further Lubbe and Murray Farlam and Hathaway - Contract 167; Van der Merwe et al Contract: General Principles 49; Hutchison and Van Heerden 1987 SALJ 524.

47 This would seem to be the effect of some dicta, compare e.g. Musgrove and Watson (Rhodesia) Ltd v Rotta 19784 SA 656 (RA) 658B; Kok v Osborne 19934 SA 788 (SE) 800C-D; see further Musgrove and Watson (Rhod) (Pvt) Ltd v Rotta 19782 SA 918 (R) 925D.

48 Compare the following dictum of Jones $\mathrm{J}$ in Kok $v$ Osborne 19934 SA 788 (SE) 800C-D: "To be the victim of the fraud of another is not, of course, per se unreasonable. ... Indeed, without detracting from the duty of every person to take proper precautions to protect himself from harm, the law should be slow to favour the ruthless, the unprincipled, and the skilfully and deliberately deceptive at the expense of a person with a trusting disposition; it will be slow to categorise his trust as unreasonable".

49 See e.g. Slip Knot Investments v Du Toit 20114 SA 72 (SCA) paras 11-12.

50 In fact Slip Knot $v$ Du Toit 20114 SA 72 (SCA) provides a striking example of how the same facts can be interpreted to justify a lack of contractual liability on the basis of iustus error (the court a quo decision) and the imposition of liability on the grounds of reliance (the Supreme Court of Appeal decision). Consequently, it is fair to say that the parallel application of these principles within third-party fraud situations may frequently result in direct contradiction (see further Pretorius 2011b THRHR 191).

51 Hutchison "Contract Formation" 191-192; Hutchison and Van Heerden 1987 SALJ 525; Pretorius 2004b THRHR 558.

52 See further Pretorius 2011b THRHR 191-192; see Hutchison "'Traps For the Unwary'" 56ff; Lewis 1987 SALJ 375-377.

53 Slip Knot Investments $v$ Du Toit 20114 SA 72 (SCA) 76E-77A. 
(D)id the party whose actual intention did not conform to the common intention expressed, lead the other party, as a reasonable man, to believe that his declared intention represented his actual intention? ... To answer this question, a three-fold enquiry is usually necessary, namely, firstly, was there a misrepresentation as to one party's intention; secondly, who made that representation; and thirdly, was the other party misled thereby? ... The last question postulates two possibilities: Was he actually misled and would a reasonable man have been misled?

And appropriately, although the respondent pleaded his defence in terms of iustus error, Malan JA preferred to apply the reliance theory in the circumstances:

In argument before us counsel for the respondent expressly disavowed that the respondent was misled by Slip Knot - whether by reason of the form in which the documents were couched or in any other way. To the extent that the respondent was misled he placed the blame squarely and solely at the doors of his brother and nephew. Nor is there any suggestion that the fraud or misrepresentation of the respondent's relatives could or should be attributed to Slip Knot. There is every reason to infer that Slip Knot, as a reasonable person, believed that the respondent's declared intention to be bound as surety as evidenced by his signature to the suretyship also represented his real intention. The respondent entered into the suretyship relying, not on any representation by Slip Knot, but on representations made to him by his nephew and conveyed to him by Altro Potgieter. ${ }^{55}$

In the result it is fair to state that the Supreme Court of Appeal has provided much needed direction in two respects: firstly, generally speaking where material mistake has been induced by the fraud of an independent third party a contract nevertheless may still arise; and secondly, the favoured approach to determining liability appears to be the reliance theory. ${ }^{56}$ Although the iustus error doctrine was not expressly discounted in the circumstances, the general tenor of the judgment suggests that the reliance theory is the preferable route to follow. Appropriately also there was no direct enquiry as to fault on the part of the contract denier. It is submitted that the approach of the court is to be welcomed for bringing an element of clarity on a sound

54 Sonap Petroleum (SA) (Pty) Ltd v Pappadogianis 19923 SA 234 (A) 239I-240B.

55 Sonap Petroleum (SA) (Pty) Ltd v Pappadogianis 19923 SA 234 (A) para 11.

56 In this regard Slip Knot Investments $v$ Du Toit 20114 SA 72 (SCA) ties in with what appears to be a growing trend of the Supreme Court of Appeal to favour the reliance theory and on occasion expand its application - compare e.g. Cape Group Construction (Pty) Ltd t/a Forbes Waterproofing $v$ Government of the United Kingdom 20035 SA 180 (SCA) para 22; Constantia Insurance Co Ltd v Compusource (Pty) Ltd 20054 SA 345 (SCA) para 17; Cecil Nurse (Pty) Ltd v Nkola 20082 SA 441 (SCA) para 15; Hartley v Pyramid Freight (Pty) Ltd t/a Sun Couriers 2007 2 SA 599 (SCA) para 6; Be Bop a Lula Manufacturing and Printing CC v Kingtex Marketing (Pty) Ltd 20083 SA 327 (SCA) para 10; Pillay v Shaik 20094 SA 74 (SCA) para 55. 
theoretical basis to a section of the law of mistake that has been problematic since its fledgling years. ${ }^{57}$

\subsection{Exceptions based on policy considerations}

Although the judgment of Malan JA implies that third-party fraud does not negate contractual liability in terms of the reliance theory, it remains unclear whether this must be taken as a strict rule or whether there may yet be policy-driven exceptions in deserving instances. It is suggested that while a general rule or principle is essential to achieve a measure of legal certainty, there could be exceptions based on policy considerations peculiar to specific cases. ${ }^{58}$ This argument is strengthened by case law, which acknowledges that a mistaken party may be absolved from liability in appropriate circumstances. ${ }^{59}$ Although the authoritative formulation of the reliance theory in Sonap Petroleum (SA) (Pty) Ltd $v$ Pappadogianis ${ }^{60}$ does not expressly make allowance for third-party fraud, ${ }^{61}$ conceivably a court may entertain relevant policy factors under the open-ended, normative element of reasonableness. ${ }^{62}$ Another possibility, loosely based on an analogy with estoppel, is that the reliance theory may be developed to include an element of legal causation in terms of which instances of third-party fraud may be dealt with. Above all, the approach should be flexible and pragmatic to enable a court on the basis of relevant policy considerations to depart from the general premise that third-party fraud does not preclude contractual liability. ${ }^{63}$

57 Compare eg Standard Bank v Du Plooy; Standard v Coetzee 189916 SC 161 168, 172; Siffman v Kriel 1909 TS 538546.

58 Compare also Christie and Bradfield Christie's The Law of Contract 331-332; see further FévrierBreed 1995 TSAR $304 f f$.

59 Saambou-Nasionale Bouvereniging v Friedman 19793 SA 978 (A) 1000B; Musgrove and Watson (Rhodesia) Ltd $v$ Rotta 19784 SA 656 (RA) 658B; Musgrove and Watson (Rhod) (Pvt) Ltd v Rotta 19782 SA 918 (R) 925D; Kok v Osborne 19934 SA 788 (SE) 800C-D; Standard Credit Corporation Ltd v Naicker 19872 SA 49 (N) 52B-C; Standard Bank v Du Plooy; Standard Bank v Coetzee 189916 SC 161 172. Incidentally one finds similar ambiguity in positive law throughout the law of obligations, where the deliberate intervention of a third party is involved, suggesting that there is no single rule or principle that fits all cases (see Pretorius 2011b THRHR 205-207).

60 Quoted at para 4.2

61 See Floyd and Pretorius 1992 THRHR 673.

62 On this element of reliance see further Van der Merwe et al Contract: General Principles 40-41; Pretorius 2005b THRHR 585-586.

63 For a detailed account see Pretorius 2011b THRHR 192-195.

$198 / 261$ 
A number of policy considerations could potentially influence a court's decision where third-party fraud is involved, ${ }^{64}$ but two may be specifically mentioned. In the first place there is the element of risk inherent in choosing a messenger to convey communications between parties. If the contract assertor chooses an independent third party to act as messenger between the parties, he or she should bear the consequences of a material mistake on the part of the contract denier caused by the fraudulent misrepresentation of the messenger. In such circumstances the principle of risk ${ }^{65}$ could indicate that ultimately the contract assertor's reliance was not reasonable. ${ }^{66}$ In the second place one may consider the question of prejudice. ${ }^{67}$ Where the contract assertor has not incurred expenses or otherwise detrimentally altered his or her position, and where the status quo can easily be restored, it may be an indication that liability should not lie. ${ }^{68}$ These are but examples of factors that could sway the equities in favour of the contract denier; however, a court will probably have to be convinced that there clearly is good reason to deviate from the approach in Slip Knot Investments $v$ Du Toit.

\subsection{Suretyships and third-party fraud}

It may also briefly be mentioned that third-party fraud often seems to surface within the context of suretyship agreements. Typically, the contract denier is misled by the third party into believing that he or she is signing something other than a suretyship -

64 See further Pretorius 2011b THRHR 193-194.

65 The risk theory or principle may be employed as a possible corrective to the will theory in that a party who by his or her conduct creates the risk of dissensus, and disagreement eventuates, may be held liable on the basis of risk assumption. Although not an independent ground for contractual liability, risk can be accommodated within present contract theory as a factor that may influence the reasonableness of a party's conduct (see generally Hofmann 1935 SALJ 436; Floyd and Pretorius 1992 THRHR 672-673; Pretorius 2005a THRHR 453 footnote 79; see further Lubbe and Murray Farlam and Hathaway - Contract 163).

66 See further Kok v Osborne 19934 SA 788 (SE) 800; Floyd and Pretorius 1994 THRHR 328.

67 This consideration is based on an analogy with estoppel with its close ties to the reliance theory (see generally Christie and Bradfield Christie's The Law of Contract 26-30; De Wet and Van Wyk Suid-Afrikaanse Kontraktereg 21 and further; Rabie and Sonnekus Law of Estoppel 194-196; Hutchison and Pretorius Law of Contract 92-97; Pretorius 2004a THRHR 389-393).

68 See further Musgrove and Watson (Rhod) (Pvt) Ltd v Rotta 19782 SA 918 (R) 926B-E; Musgrove and Watson (Rhodesia) Ltd v Rotta 19784 SA 656 (RA) 658B-C; De Wet and Van Wyk Suid-Afrikaanse Kontraktereg 22; Lubbe and Murray Farlam and Hathaway - Contract 167168. 
an onerous agreement by its very nature. ${ }^{69}$ Generally where a representative of some or other legal entity signs a personal suretyship agreement as security for the debts of the entity and then pleads justifiable mistake when the suretyship is enforced, the courts have been wary of lightly absolving the surety from the liability. ${ }^{70}$ Where, however, there have been clear indications of underhandedness on the part of the creditor they have not hesitated in striking down the agreement. ${ }^{71}$ The fairly strict approach that the courts have followed in this regard, especially since the caveat subscriptor rule applies, ${ }^{72}$ is a reminder that traditionally the scope for a successful plea of unilateral mistake has been rather limited. ${ }^{73}$ Although on the other hand on occasion the provincial courts have perhaps been a little too lenient, ${ }^{74}$ Slip Knot confirms that the signatory of a contractual document embodying a suretyship will not easily escape liability, even where his or her actions are the result of the fraudulent endeavours of a third party.

Some may consider the decision in Slip Knot quite harsh, especially since the signatory had no interest in the documents that he was signing. This case also contrasts rather starkly with the Supreme Court of Appeal decision in Brink $v$ Humphries \& Jewell (Pty) $L t d,{ }^{75}$ where an otherwise astute businessman and director of a company signed a one-page document (on behalf of the company) that

69 See e.g. Standard Bank v Du Plooy; Standard Bank v Coetzee 189916 SC 161; Musgrove and Watson (Rhod) (Pvt) Ltd v Rotta 19782 SA 918 (R); Musgrove and Watson (Rhodesia) Ltd $v$ Rotta 19784 SA 656 (RA); Khan v Naidoo 19893 SA 724 (N).

70 Compare eg Roomer v Wedge Steel (Pty) Ltd 19981 SA 538 (N); Diners Club SA (Pty) Ltd v Thorburn 19902 SA 870 (C); Tesoriero v Bhyjo Investments Share Block (Pty) Ltd 20001 SA 167 (W); Blue Chip Consultants (Pty) Ltd v Shamrock 20023 SA 231 (W); Advanced Mechanical and Lubrication Technology (Pty) Ltd v Conradie Ontwikkelings BK $2006 \mathrm{JOL} 16692$ (T); Langeveld v Union Finance Holdings (Pty) Ltd 20074 SA 572 (W); Royal Canin South Africa (Pty) Ltd v Cooper 20086 SA 644 (SE); see further Stiff $v$ Q Data Distribution (Pty) Ltd 20032 SA 336 (SCA); Cecil Nurse (Pty) Ltd v Nkola 20082 SA 441 (SCA).

71 See eg Prins v Absa Bank Ltd 19983 SA 904 (C) 911D; Davids v Absa Bank Bpk 20053 SA 361 (C) para 23.

72 In terms of s 6 General Law Amendment Act 50 of 1956 a suretyship must be embodied in a document signed by or on behalf of the surety. This provision seeks to promote legal certainty and also possibly to bring the contractual provisions to the attention of the surety given the onerous nature of suretyships (see Fourlamel (Pty) Ltd v Maddison 19771 SA 333 (A) 342-343; Forsyth and Pretorius Caney's The Law of Suretyship 67-69).

73 National and Overseas Distributors Corporation (Pty) Ltd v Potato Board 19582 SA 473 (A) 479G-H; Diners Club SA (Pty) Ltd v Thorburn 19902 SA 870 (C) 874D-E; Christie and Bradfield Christie's Law of Contract 329.

74 See eg Keens Group Co (Pty) Ltd v Lötter 19891 SA 585 (C). For justified criticism of this decision see Sharrock 1989 SALJ 458 and further.

75 Brink v Humphries and Jewell (Pty) Ltd 20052 SA 419 (SCA). 
contained a personal suretyship clause without reading it, although he had ample opportunity to do so. The court upheld the signatory's plea of iustus error because the form was "a trap for the unwary" and the signatory was justifiably misled by it. ${ }^{76}$ This decision has drawn criticism ${ }^{77}$ and the courts seem hesitant to apply it. ${ }^{78}$ Nevertheless, in reaching his conclusion in Slip Knot Malan JA seemed to emphasise that as a trustee of a trust the signatory should have duly observed his duties and, more importantly, the creditor was entitled to rely on his signature on the suretyship just as much as it was justified in relying on his signature on the other trust documents. In this regard Slip Knot perhaps suggests a stricter approach than was adopted in Brink to instances where directors of companies, members of close corporations, trustees of trusts and the like sign contractual documents relating to the dealings of the entity represented. ${ }^{79}$

\section{Conclusion}

The question of whether or not the material mistake of a contractant induced by the fraud of an independent third party is sufficient to sustain a plea of iustus error or a lack of reasonable reliance has finally been settled by the Supreme Court of Appeal. Slip Knot Investments $v$ Du Toit confirms that in such instances the mistaken party will not be exonerated from contractual liability where the other contractual party has been led to reasonably believe that the mistaken party has bound him- or herself to the juristic act in question. The situation in this regard now broadly mirrors the legal position where a third party fraudulently induces a non-material mistake on the part of a contractant: the fraud of the third party does not affect contractual liability where there is in fact consensus ad idem (in cases of non-material mistake) or reasonable reliance (in cases of material mistake).

76 Brink v Humphries and Jewell (Pty) Ltd 20052 SA 419 (SCA) 426C.

77 See e.g. Hutchison "Contract Formation" 41-42, 47-52, 57-58; Bhana and Nortjé 2005 Annual Survey of South Africa $208 \mathrm{ff}$.

78 See e.g. Royal Canin South Africa (Pty) Ltd v Cooper 20086 SA 644 (SE) 647-648.

79 Regarding mistake and suretyships see further Forsyth and Pretorius Contract Law Casebook 64-67; Otto 2005 TSAR 805 and further; Cilliers and Luiz 1996 THRHR 168ff; Pretorius 2009 Obiter 763 and further. 
The position prior to this decision was characterised by uncertainty and contradiction largely caused by applying the iustus error approach and the question of negligence on the part of the contract denier to third-party fraud situations. The iustus error doctrine proves indeterminate in such instances because it could provide the reason either for contractual liability (if negligence on the part of the contract denier is regarded as decisive) or the lack thereof (if negligence on the part of the contract denier is automatically negated by the fraud of the third party). Earlier decisions reflect the ambivalence that the iustus error doctrine suffers from in this regard. Moreover, even if the conduct of the mistaken party is regarded as excusable for being induced by the fraud of a third party, there would still almost inevitably be conflict between the iustus error approach and reliance theory where the belief of the contract assertor in consensus was reasonable in the circumstances. Although in Slip Knot the court did not expressly exclude the iustus error approach from thirdparty fraud cases, it clearly favoured the application of the reliance theory in such circumstances. Justification for this proposition may be derived from the fact that although the case was pleaded in terms of iustus error, the court regarded the test for reliance as decisive in the circumstances and clearly applied it to the facts. It is suggested that the law of mistake would benefit from express exclusion of the iustus error doctrine from third-party fraud situations.

It is further submitted that there may in fact be exceptional cases where the mistaken party should be relieved from contractual liability on the basis of policy considerations peculiar to the specific circumstances. In this manner reliance which at first seems reasonable for being induced by the conduct of the contract denier may upon further reflection be regarded as unreasonable based on, for instance, the consideration of risk creation at the hand of the contract assertor who has insisted on a specific third party as messenger between the contractants, and who perpetrates the fraud. Admitting exceptions in appropriate circumstances would provide a measure of consonance with earlier case law where a court has intuitively felt that liability should not lie, even if the court's approach was open to theoretical criticism. 


\section{Bibliography}

Bhana and Nortjé 2005 Annual Survey of South African Law

Bhana D and Nortjé M "General Principles of Contract" 2005 Annual Survey of South African Law 196-252

Christie and Bradfield Christie's The Law of Contract

Christie RH and Bradfield GB Christie's The Law of Contract in South Africa $6^{\text {th }}$ ed (LexisNexis Durban 2011)

Cilliers and Luiz 1996 THRHR

Cilliers JB and Luiz SM "Caveat Subscriptor - Beware the Hidden Suretyship Clause" 1996 THRHR 168-175

De Wet and Van Wyk Suid-Afrikaanse Kontraktereg

De Wet JC and Van Wyk AH Die Suid-Afrikaanse Kontraktereg en Handelsreg Vol $15^{\text {th }}$ ed (Butterworths Durban 1992)

Février-Breed 1995 TSAR

Février-Breed $\mathrm{P}$ "A Perspective on the Justus-requirement in Justus Error" 1995 TSAR 300-309

Février-Breed 1996 THRHR

Février-Breed P "The 'Fault Principle' and Justus error in Mistake in Contract" 1996 THRHR 209-218

Floyd 1996 THRHR

Floyd TB "Die Begrip Ooreenkoms - 'n Bydrae tot die Teorie van Regsfeite" 1996 THRHR 557-576 
Floyd and Pretorius 1992 THRHR

Floyd TB and Pretorius C-J "A Reconciliation of the Different Approaches to Contractual Liability in the Absence of Actual Consensus" 1992 THRHR 668673

Floyd and Pretorius 1994 THRHR

Floyd TB and Pretorius C-J "Mistake and Supervening Impossibility of Performance" 1994 THRHR 325-329

Forsyth and Pretorius Caney's The Law of Suretyship

Forsyth CF and Pretorius JT Caney's The Law of Suretyship $6^{\text {th }}$ ed (Juta Cape Town 2010)

Hawthorne and Pretorius Contract Law Casebook

Hawthorne L and Pretorius C-J Contract Law Casebook $3^{\text {rd }}$ ed (Juta Cape Town 2010)

Hofmann 1935 SALJ

Hofmann LC "The Basis of the Effect of Mistake on Contractual Obligations" 1935 SALJ 432-449

Hutchison "Contract Formation"

Hutchison D "Contract Formation" in Zimmermann R and Visser D (eds) Southern Cross: Civil Law and Common Law in South Africa (Clarendon Press Oxford 1996) 165-194

Hutchison "'Traps For the Unwary"'

Hutchison D "'Traps For the Unwary': When Careless Errors are Excusable" in Glover G (ed) Essays in Honour of AJ Kerr (LexisNexis Durban 2006) 39-58

Hutchison and Pretorius Law of Contract

Hutchison D and Pretorius C-J (eds) The Law of Contract in South Africa (Oxford Cape Town 2009) 
Hutchison and Van Heerden 1987 SALJ

Hutchison D and Van Heerden BJ "Mistake in Contract: A Comedy of (Justus) Errors" 1987 SALJ 523-530

Joubert General Principles of the Law of Contract

Joubert DJ General Principles of the Law of Contract (Juta Cape Town 1987)

Kerr Principles of the Law of Contract

Kerr AJ The Principles of the Law of Contract $6^{\text {th }}$ ed (Butterworths Durban 2002)

Lewis 1987 SALJ

Lewis C "Caveat Subscriptor and the Doctrine of Justus Error" 1987 SALJ 371-377

Lubbe and Murray Farlam and Hathaway - Contract

Lubbe GF and Murray CM Farlam and Hathaway - Contract: Cases, Materials and Commentary $3^{\text {rd }}$ ed (Juta Cape Town 1988)

Otto 2005 TSAR

Otto JM "Verskuilde Borgstellings in Standaardkontrakte en lustus Error" 2005 TSAR 805-814

Pretorius 2004a THRHR

Pretorius C-J "The Basis of Contractual Liability in South African Law (2)" 2004 THRHR 383-393

Pretorius 2004b THRHR

Pretorius C-J "The Basis of Contractual Liability in South African Law (3)" 2004 THRHR 549-565 
Pretorius 2005a THRHR

Pretorius C-J "The Basis of Contractual Liability (2): Theories of Contract (Will and Declaration)" 2005 THRHR 441-460

Pretorius 2005b THRHR

Pretorius C-J "The Basis of Contractual Liability (3): Theories of Contract (Consideration, Reliance and Fairness)" 2005 THRHR 575-593

Pretorius 2009 Obiter

Pretorius C-J "Mistake and Suretyship: Avoiding the Spectre of Brink $v$ Humphreys \& Jewell (Pty) Ltd" 2009 Obiter 763-773

Pretorius 2011a THRHR

Pretorius C-J "Deliberate Third Party Conduct and the Creation of Obligations (1): Delict and Unjustified Enrichment" 2011 THRHR 65-86

Pretorius 2011b THRHR

Pretorius C-J "Deliberate Third Party Conduct and the Creation of Obligations (2): Contract and Estoppel" 2011 THRHR 182-207

Rabie and Sonnekus Law of Estoppel

Rabie PJ and Sonnekus JC The Law of Estoppel in South Africa $2^{\text {nd }}$ ed (Butterworths Durban 2000)

Sharrock 1989 SALJ

Sharrock RD "Inappropriate Wording in a Contract: A Basis for the Defence of Iustus Error?" 1989 SALJ 458-464

Van der Merwe et al Contract: General Principles

Van der Merwe S et al Contract: General Principles $3^{\text {rd }}$ ed (Juta Cape Town 2007) 
Van der Merwe and Van Huyssteen 1993 TSAR

Van der Merwe $S$ and Van Huyssteen LF "Kontraksluiting en Toerekenbare Skyn" 1993 TSAR 493-497

Van Rensburg 1986 THRHR

Van Rensburg ADJ "Die Grondslag van Kontraktuele Gebondenheid" 1986 THRHR 448-459

Van Rensburg et al "Contract"

Van Rensburg ADJ et al "Contract" in Joubert WA, Faris JA and Harms LTC (eds) The Law of South Africa Volume 5 Part $12^{\text {nd }}$ ed (LexisNexis Durban 2004)

Wessels Wessels' Law of Contract

Roberts AA Wessels' Law of Contract in South Africa Volume $12^{\text {nd }}$ ed (Butterworth Durban 1951)

\section{Register of cases}

Advanced Mechanical \& Lubrication Technology (Pty) Ltd $v$ Conradie Ontwikkelings BK 2006 JOL 16692 (T)

Afrox Healthcare Bpk v Strydom 20026 SA 21 (SCA)

Be Bop a Lula Manufacturing \& Printing CC v Kingtex Marketing (Pty) Ltd 20083 SA 327 (SCA)

Blue Chip Consultants (Pty) Ltd v Shamrock 20023 SA 231 (W)

Bodemer v American Insurance Co 19612 SA 662 (A)

Brink v Humphries \& Jewell (Pty) Ltd 20052 SA 419 (SCA)

Cape Group Construction (Pty) Ltd t/a Forbes Waterproofing $v$ Government of the United Kingdom 20035 SA 180 (SCA)

Cecil Nurse (Pty) Ltd v Nkola 20082 SA 441 (SCA)

Constantia Insurance Co Ltd v Compusource (Pty) Ltd 20054 SA 345 (SCA)

Davids v Absa Bank Bpk 20053 SA 361 (C)

Diners Club SA (Pty) Ltd v Thorburn 19902 SA 870 (C) 
Du Toit v Atkinson's Motors Bpk 19852 SA 893 (A)

Fedbond Nominees (Pty) Ltd v Meier 20081 SA 458 (C)

Fourie $v$ Hansen 20011 All SA 510 (W)

Fourlamel (Pty) Ltd v Maddison 19771 SA 333 (A)

George v Fairmead (Pty) Ltd 19582 SA 465 (A)

Hartley v Pyramid Freight (Pty) Ltd t/a Sun Couriers 20072 SA 599 (SCA)

Hlobo v Multilateral Motor Vehicle Accidents Fund 20012 SA 59 (SCA)

Horty Investments (Pty) Ltd v Interior Acoustics (Pty) Ltd 19843 SA 537 (W)

Karabus Motors (1959) Ltd $v$ Van Eck 19621 SA 451 (C)

Keens Group Co (Pty) Ltd v Lötter 19891 SA 585 (C)

Khan v Naidoo 19893 SA 724 (N)

Kok $v$ Osborne 19934 SA 788 (SE)

Langeveld v Union Finance Holdings (Pty) Ltd 20074 SA 572 (W)

Musgrove and Watson (Rhod) (Pvt) Ltd v Rotta 19782 SA 918 (R)

Musgrove and Watson (Rhodesia) Ltd v Rotta 19784 SA 656 (RA)

National and Overseas Distributors Corporation (Pty) Ltd v Potato Board 19582 SA $473(\mathrm{~A})$

Pillay $v$ Shaik 20094 SA 74 (SCA)

Potgieter v British Airways plc 20053 SA 133 (C)

Prins v Absa Bank Ltd 19983 SA 904 (C)

Roomer v Wedge Steel (Pty) Ltd 19981 SA 538 (N)

Royal Canin South Africa (Pty) Ltd v Cooper 20086 SA 644 (SE)

Saambou-Nasionale Bouvereniging v Friedman 19793 SA 978 (A)

Siffman $v$ Kriel 1909 TS 538

Slip Knot Investments v Du Toit 20114 SA 72 (SCA)

Sonap Petroleum (SA) (Pty) Ltd v Pappadogianis 19923 SA 234 (A)

Spindrifter (Pty) Ltd v Lester Donovan (Pty) Ltd 19861 SA 303 (A)

Standard Bank v Du Plooy; Standard Bank v Coetzee 189916 SC 161

Standard Credit Corporation Ltd v Naicker 19872 SA 49 (N)

Stiff v Q Data Distribution (Pty) Ltd 20032 SA 336 (SCA)

Tesoriero v Bhyjo Investments Share Block (Pty) Ltd 20001 SA 167 (W)

Trans-Drakensberg Bank Ltd v Guy 19641 SA 790 (D)

Western Province Wine Depot Ltd v Bellingham 19661 SA 349 (T) 


\section{Register of legislation}

General Law Amendment Act 50 of 1956

\section{List of abbreviations}

SALJ South African Law Journal

THRHR Tydskrif vir Hedendaagse Romeins-Hollandse Reg

TSAR Tydskrif vir die Suid-Afrikaanse Reg 